\title{
Krisekommunikation i kommunerne
}

Søren Stentoft Herping ph.d. stipendiat, Institut for Statskundskab, Aalborg Universitet

At tænke "hvis krisen opstår" er ønsketænkning. Udgangspunktet for et kriseberedskab er mere realistisk "når krisen opstår" (KL 2008, 19).

I slutningen af februar 2010 blev den relativt ukendte Brønderslev Kommune genstand for den danske verdenspresses bevågenhed. Sagen om den store, dysfunktionelle familie med historier om vold, seksuelt misbrug og vanrøgt i dagligdagen gik landet rundt. Fokus kom ret hurtigt på Brønderslev Kommunes rolle, der pludselig befandt sig i orkanens øje. Denne artikel vil med udgangspunkt i den såkaldte Brønderslevsag belyse nogle af de problemstillinger, der opstod i den første kritiske fase, da kommunen skulle ud i krisekommunikationens svære kunst.

\section{Introduktion}

Da Brønderslev Kommune fredag d. 26. februar 2010 fik den samlede danske presses bevågenhed, blev den endnu en kommune, der måtte sande, at krisekommunikation og krisehåndtering er en svær størrelse. Før den har eksempelvis Tønder, Aalborg og Aarhus Kommune haft socialsager, der illustrerer behovet for, at kommunerne bliver bedre til at håndtere kriser. KL har fra sin side haft en del fokus på området. Der er udfærdiget temaguider (KL 2008), skrevet temanumre af kommunernes eget magasin om emnet (Danske Kommuner 2010) og krisekommunikation er blevet en del af konsulentydel- serne (http://www.kl.dk/Fagomrader/Kommunikation/ Konsulentydelser/). Der kan være flere grunde til, at KL har øget sit fokus på krisekommunikationen. En af dem kan være, at der er kommet mere fokus på kommunernes omdømme (Frandsen et. al 2005). En anden begrundelse kan hænge sammen med den ændrede legitimitetsopfattelse, som er en del af den NPM-inspirerede tilgang, hvor borgere gøres til brugere (Christensen \& Lægreid 2009), hvilket ændrer legitimitetsopfattelsen i den offentlige sektor (Peters 1998). Der er med andre ord gode argumenter for, at kommunerne bliver bedre til at håndtere deres omdømme i forhold til deres dynamiske omgivelser. Krisekommunikation er en af de metoder, der kan anvendes til at beskytte omdømmet (Johansen \& Frandsen 2007).

På forskningssiden er der efterhånden flere studier af krisekommunikation i den offentlige sektor, men de fleste har fokus på katastrofer som eksempelvis orkaner, terror eller naturkatastrofer (se eksempelvis Andersen 2008). I en dansk kontekst ses dette også ved, at Johansen \& Frandsen (2009) har set på den krisekommunikative perception hos henholdsvis beredskabschefer og kommunikationschefer i kommunerne.

Hvad angår kriseledelse så har Boin \& t' Hart (2003) og Boin et. al. (2005) beskæftiget sig med kriseledelse i en offentlig kontekst, men fælles for disse studier er, at de fokuserer på regeringers krisehåndtering. På kommunalt niveau findes kun ganske lidt. Ydermere ser det ud som om, at kriseledelse og krisekommunikation er to særskilte forskningsområder, der har meget få overlap med hinanden. Denne undersøgelse vil prøve at bygge bro mellem 
de to forskningstraditioner ved at undersøge ledelsen af en krise samtidig med, at der krisekommunikeres. Det er dette forskningshul samt det stærke empiriske fokus, som denne undersøgelse prøver at sætte lys på gennem et case studie af den såkaldte Brønderslevsag. Formålet med undersøgelsen er todelt. I første omgang opstilles en teoretisk model for krisekommunikation, der trækker på teori fra krisekommunikationslitteraturen samt teorier om beslutningsprocesser i offentlige organisationer. Herefter søges en tentativ, empirisk afprøvning af teorien gennem et deduktivt, single case design. Dette sker i en analyse af Brønderslevsagens første fem dage. Disse dage er også de dage, hvor Brønderslev Kommune er mest under pres, og hvor de er mest uforberedte. Håbet er derfor, at denne periode giver et mere synligt indblik i krisehåndtering og krisekommunikation. ${ }^{1}$ Det empiriske undersøgelsesspørgsmål er; Hvad kommunikerer Brønderslev Kommune i forbindelse med den såkaldte Brønderslevsag, og hvordan kan denne krisekommunikation forklares?

\section{Krisekommunikation og kommuner}

Krisekommunikation kan defineres som en;

Kompleks og dynamisk konfiguration af kommunikationsprocesser - før, under og efter en begivenhed, en situation eller et forløb, der af organisationen og/eller en eller flere af dens stakeholdere fortolkes som en krise - hvor forskellige aktører, kontekster og diskurser (manifesteret i bestemte genrer og tekster) står i relation til hinanden (Johansen \& Frandsen 2007, 281).

For det første betyder ovennævnte definition, at krisekommunikation er noget, der ikke blot foregår under den begivenhed, som vi typisk betegner som krisen, men det foregår også før og efter begivenheden. Krisekommunikation er således noget, der indskriver sig i en organisatorisk proces. For det andet betyder definitionen, at der er en krise i en organisation, når der er nogen - internt eller eksternt - der mener, der er en krise. Til den sidste del af definitionen har Johansen og Frandsen opbygget en teori, der bygger på stakeholdernetværk. Ved en krise konstitueres en retorisk arena med flere forskellige aktører, der har forskellige opfattelser af, hvad krisen handler om, og hvor omfangsrig den er. Disse stakeholdere indgår i en flerhed af kommunikationsformer, hvor de kommunikerer med, mod, om, til eller forbi hinanden (Johansen \& Frandsen 2007). Det centrale er, at alle kommunikationsformerne er på spil, og for en organisation i krise handler det om, at kunne forholde sig til de forskellige aktører og de forskellige kommunikationsformer, så budskabet kan komme ud og dermed påvirke opfattelsen af krisen i arenaen.
Dette rejser imidlertid en særlig problemstilling i forhold til kommuner, der her anskues som en organisationstype med visse særtræk og dermed visse iboende spændinger, hvormed der ikke er tale om, at kommunen anses som en enhedsaktør. Tre spændinger kan klargøre synet på kommunens kompleksitet som organisation, hvilket også har betydning for de krisekommunikative muligheder. For det første kan der være rene politiske spændinger. Her vil det politiske niveau i organisationen (byrådet) være uenige, og derfor vil denne uenighed også sætte bestemte rammer, når der skal kommunikeres. For det andet kan der være spændinger mellem det politiske niveau og embedsmændene. En undersøgelse efter strukturreformen viser, at flere politikere føler at de ikke kan komme igennem med deres politiske målsætninger, fordi de bremses af ledende embedsmænd (Kjær, Hjelmar \& Olsen 2010)². Den tredje spænding er internt i administrationen. Her kan der være forskellige interesser at varetage, hvilket både kan være et resultat af hierarkiet i administrationen eller diverse faggrupper imellem. Disse spændinger, der bryder med forestillingen om kommunen som enhedsaktør, er noget af det, som KL i sine anbefalinger ikke italesætter i nævneværdig grad (KL 2008), men som er noget af det, der er en særlig udfordring, når krisekommunikation skal tages ud af dets generiske udgangspunkt i den private sektor og overføres til en kommunal kontekst.

Undersøgelsen har ligeledes til hensigt at undersøge, hvad der kan forklare krisekommunikation. Til det karakteriseres tre faktorer, der stammer fra litteraturen om beslutningstagning i offentlige organisationer (Egeberg 1992, 2003) $)^{3}$. Den første af disse er struktur, der kan karakteriseres som en formel struktur, hvor medlemmernes position og tilknytning er blevet ekspliciteret og defineret uafhængigt af de personlige karakteristika (Scott 2003). I denne undersøgelse er struktur et spørgsmål om formel struktur og strategi. I forhold til den formelle struktur ses der på den overordnede organisering af kommunikationsopgaven, hvor det specielt er adgangen til topledelsen, der kan have betydning (Lund \& Nyegaard 2008). Strategien kan både være eksistensen af en kommunikationsstrategi og/eller kriseplan, der også har fokus på kommunikation.

Et andet element er kulturen, der typisk dækker over de uformelle normer og værdier, der bliver til og er indlejret i en organisation (Christensen et. al. 2004). I denne undersøgelse oversættes dette til krisebevidsthed og kommunikativ bevidsthed. Det betyder, at fokus lægges på at identificere medlemmerne i organisationens bevidsthed om kriser og deres potentiale samt strategisk kommunikations betydning i dagligdagen. Kommunikationens betydning i dagligdagen er også relevant ud fra en anden betragtning. Teorierne om omdømmeledelse opererer også med begrebet omdømmekapital, der er det om- 
dømme en organisation har inden eksempelvis en krise. En krise er også en krise for en kommunes omdømme, hvorfor der skal trækkes på det omdømme, organisationen allerede har. Forskning viser, at organisationer med et positivt omdømme, har større mulighed for at have et bedre omdømme, når krisen er slut end organisationer med et dårligere omdømme (Coombs 2007b) eller, som KL udtrykker det;

En kommune, der ikke har „sparet op i fredstid“, vil være ekstra sårbar, når krisen er en realitet (KL 2009, 5).

Hvad angår krisebevidstheden, så har Weick \& Sutcliffe (2007) skrevet om bevidstheden hos det, de kalder High Resilience Organizations (HRO). Fællestræk for organisationer, der har en stærk bevidsthed omkring krisers potentiale er blandt andet, at de formår at agere sin egen djævlens advokat, så de selv kan agere på deres egne selvfølgeligheder inden det bliver til egentlige kriser.

Den sidste faktor, der vil blive brugt til at forklare krisekommunikationen, er demografi. Med organisationsdemografi er fokus på de egenskaber, som folk bringer med ind i organisationen (Egeberg 1992). Uddannelse og tidligere erfaring står centralt i denne sammenhæng, men også anciennitet i organisationen er relevant. Demografi kan også dække over antallet af bestemte faggrupper i en organisation, og i denne undersøgelse vil antallet af kommunikationsfolk blive undersøgt som en del af demografien.

Den teoretiske model kan sammenfattes i nedenstående figur.

I venstre side er de forklarende, intraorganisatoriske faktorer. Organisationens krisekommunikation er illustreret i de store pile fra venstre mod højre. Kommunikationen kommer til udtryk i de retoriske responsstrategier, der er gengivet $i$ tabellen herunder. Tabellen skaber nogle

Figur 1. Teoretisk model for krisekommunikation

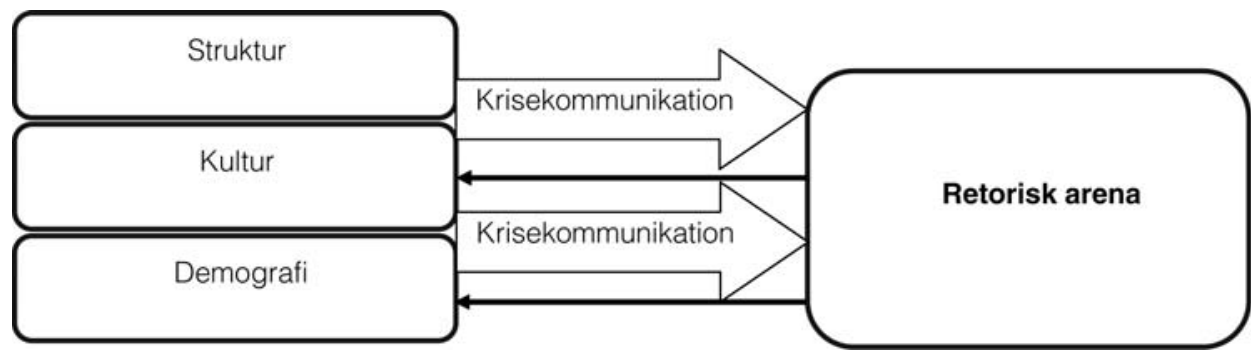

Tabel 1: Krisekommunikative responsstrategier

\begin{tabular}{|c|c|c|}
\hline Hovedkategori & Retorisk strategi & Operationalisering \\
\hline \multirow{3}{*}{ Benægtelsesstrategi } & Angrib angriberen & $\begin{array}{l}\text { Organisationen miskrediterer angriberne. Trussel om magt } \\
\text { kan anvendes }\end{array}$ \\
\hline & Benægtelse & Organisationen benægter, at der er en krise \\
\hline & Scapegoat & En anden aktør har skylden for krisen \\
\hline \multirow[b]{2}{*}{ Nedtoningsstrategi } & Unddragelse af ansvar & Organisationen prøver at minimere skylden for krisen. \\
\hline & Retfærdiggørelse & $\begin{array}{l}\text { Organisationen prøver at minimere den opfattede skade } \\
\text { ved krisen. }\end{array}$ \\
\hline \multirow{3}{*}{ Genopbygningsstrategi } & Kompensation & Der ydes erstatning til ofre \\
\hline & Undskyldning & $\begin{array}{l}\text { Organisationen indrømmer, at den har fejlet og påtager sig } \\
\text { ansvaret }\end{array}$ \\
\hline & Korrektion* & $\begin{array}{l}\text { Organisationen korrigerer handlinger, der førte til krisen, } \\
\text { således den ikke burde kunne opstå igen }\end{array}$ \\
\hline \multirow{3}{*}{ Styrkelsesstrategi } & Påmindelse & $\begin{array}{l}\text { Organisationen gør stakeholderne opmærksom på dens } \\
\text { tidligere gode arbejde }\end{array}$ \\
\hline & Indsmigre & Organisationen roser stakeholderne \\
\hline & Offerliggørelse & $\begin{array}{l}\text { Organisationen forklarer, hvordan den selv er et offer for } \\
\text { krisen. }\end{array}$ \\
\hline
\end{tabular}

(Coombs 2007a, 140)

* Benoit 1995 - egen placering i forhold til strategi. 
strategier og kategorier, som kan bruges til at typologisere selve krisekommunikationen i analysen. Kommunikationen optages i den retoriske arena, hvor det indgår $i$ en eller flere diskurser, der skaber en dynamik i arenaen, som kommunen skal reagere på, hvilket er illustreret $\mathrm{i}$ de tynde pile fra højre mod venstre. Herefter kommunikerer kommunen på de nye diskurser, og således skabes processen.

De forklarende faktorer leder til en hypotese, der går på, at et formelt vedtaget kriseberedskab med inddragelse af kommunikation, en høj grad af krisebevidsthed samt kommunikativ kriseerfaring og en strategisk bevidst kommunikationsafdeling i en kommune er en forudsætning for en stærk krisekommunikation og krisehåndtering.

\section{Case: Brønderslevsagen}

Til denne undersøgelse bruges et kvalitativt, hypotetisk deduktivt, single case design. ${ }^{4}$ Det hypotetisk deduktive kommer til udtryk ved brugen af en teoretisk model (illustreret ovenfor) og den dertilhørende hypotese. Til dette anvendes et strategisk casevalg. Brønderslev Kommune havde ikke, da sagen brød ud, et kriseberedskab, hvorimod den strategiske kommunikation var strukturelt forankret i ledelsen af organisationen. Kulturen forstået som krisebevidsthed var ikke specielt stor i den pågældende case, og kommunen har blot én kommunikationsmedarbejder. ${ }^{5}$ På den led er der tale om en worst case eller kritisk case, der tillader slutninger af karakteren, hvis det (ikke) gælder for denne case, så gælder det (ikke også) for andre cases (Antoft \& Salomonsen 2007, Flyvbjerg 2006). Logikken følger herefter, at hvis krisekommunikation og håndtering er god, så kan struktur, kultur og demografi ikke forklare eventuel succes i krisekommunikation, og dermed må den teoretiske model forkastes. Omvendt følger det, at hvis kommunikation og håndtering er gået skævt, så er der noget i teorien, der holder vand.

Et af de centrale elementer i et kvalitativt design er spørgsmålet om kausalitet. Der kan sonderes mellem to former for kausalitet, hvor den ene går på variable, mens den anden går på mekanismen (Gerring 2005, Miles \& Huberman 1994). Det, der er det kvalitative casestudies særlige styrke, er, at det giver mulighed for at åbne den sorte boks, der ligger mellem variablene, og således giver et indblik i, hvordan kausaliteten fungerer.

Qualitative analysis, with its close-up look, can identify mechanisms, going beyond sheer association. It is unrelentingly local, and deals well with the complex network of events and processes in a situation. It can sort out the temporal dimension, showing clearly what preceded what, either through direct observation or retrospection. It is well equipped to cycle back and forth between variables and processes - showing that "stories“ are not capricious, but include underlying variables, and that variables are not disembodied, but have connections over time (Miles \& Huberman 1994, 147).

Således giver det kvalitative design mulighed for at undersøge, hvordan eksempelvis strukturen har indflydelse på beslutningsprocessen omkring krisekommunikation.

Kvalitative studiers primære kritikpunkt går på problemerne omkring validiteten (Yin 2009). Bryman (2008) arbejder i den forbindelse med begreberne intern validitet og målingsvaliditet - begreber, der er hentet fra en kvalitativ logik, men som også kan bruges i en kvalitativ sammenhæng (Andersen 2010). Målingsvaliditeten kaldes også konstruktionsvaliditet og handler om, hvorvidt man også måler på det, man påstår at måle på. For at højne denne stilles der store krav til operationaliseringerne i en kvalitativ undersøgelse for at sikre overensstemmelse mellem den teoretiske og operationelle definition. Den interne validitet handler primært om kausaliteten i undersøgelsen, hvor fire kriterier kan hjælpe med at styrke det kausale argument. For det første det åbenlyse, om der kan påvises en sammenhæng. Herefter vurderes den tidsmæssige dimension for at sikre, at den forklarende faktor også tidsmæssigt kommer før der, der ønskes forklaret. Det tredje kriterium handler om, hvorvidt der kan være andre faktorer, der kan forklare kausaliteten, og til sidst bør der være en teoretisk forklaring på kausaliteten, der allerede er givet i forbindelse med gennemgangen af teorien. Ud fra disse fire dimensioner, kan kausaliteten vurderes, og det kan allerede nu klargøres, at det i et single case design som dette ikke er muligt at vurdere, hvorvidt andre faktorer kan forklare krisekommunikationen. Inden for krisekommunikationslitteraturen opererer nogle forskere med et kontingensprincip, der siger, at krisetypen har betydning for, hvordan krisen kan og bør håndteres (Coombs 2007a+b, Pearson \& Mitroff 1993). Derfor kan der gives et teoretisk argument, der går på, at krisetypen kan forklare krisehåndteringen og den efterfølgende krisekommunikation, men dette undersøges ikke her.

Undersøgelsen bygger på dokumentstudier og interviews. Kriser har den karakter, at selvom man ved, at de kommer, så er der ingen, der ved, hvornår de dukker op. Det gør, at casestudier af krisehåndtering bliver retroperspektivt. Det vilkår må man acceptere. Det betyder også, at der er en risiko for, at interviews bliver efterrationaliseringer, ligesom hukommelsen kan svigte omkring detaljer efterhånden, som tiden går. Der er foretaget interviews med alle de personer i Brønderslev 
Kommune, der har haft med håndteringen af krisen at gøre. Der er ikke fra kommunens side ønsket anonymitet, men grundet personfokusset efter DRs dokumentar „Børnene fra Brønderslev“, er interviewudsagn alligevel anonymiseret af forfatteren. Respondenter optræder som 1, 2, 3, 4, 5, 6 og 7. Respondenternes gøren er dog gengivet med betegnelser. Alle interviews er foretaget i oktober og november 2010, hvilket er ca. 8 måneder efter sagen brød ud i medierne. Hertil kommer dokumenter i form af pressemeddelelser og mails sendt fra kommunen samt avisartikler og nyhedsindslag, der omtaler sagen. I forhold til at identificere selve kommunikationen fra Brønderslev Kommune bliver spørgsmålet, hvad organisationen er, igen aktuelt. Kommunikation fra kommunen identificeres i denne undersøgelse som kommunikation, der identificerer organisationen Brønderslev Kommune som afsenderen, ligesom det også er et kriterium i denne undersøgelse, at kommunikationen kan spores tilbage til en af de syv interviewpersoner. Det betyder ikke, at det er irrelevant, hvis der er andre stemmer fra Brønderslev Kommune, der deltager i den retoriske arena (hvilket der var undervejs), men det vil i så fald være noget, som kommunen som organisation skal forholde sig til.

\section{Alt hvad der kan gå galt}

Brønderslevsagen eller Serritslevsagen, som den også kaldes, starter torsdag d. 25. februar 2010 om eftermiddagen, da politiet efter en anmeldelse fra den ældste datter, der er stukket af fra hjemmet og har anmeldt sagen, tager ud, og anholder forældrene på ejendommen i Serritslev. Parret har i alt ti sammenbragte børn, hvoraf de 9 er mindreårige på daværende tidspunkt. Sagen bliver offentligt kendt fredag d. 26. februar, da forældrene kommer i grundlovsforhør. I løbet af fredagen kommer der fokus på, hvordan det kunne gå så galt, og dermed kommer Brønderslev Kommune i søgelyset. Sagen er i juni 2011 afgjort ved retten, hvor moren og faren er dømt skyldige i næsten alle anklagepunkter. Brønderslev Kommune har modtaget kraftig kritik fra Ankestyrelsen (Brønderslev 2010a), men har fået medhold i refusion af udgifterne til anbringelse, der skal afholdes af Lollands Kommune, der er en af de kommuner, hvor familien tidligere har boet (Brønderslev 2010b) - for en tidstabel over forløbet henvises til appendix A.

Denne analyse vil undersøge den første tidlige fase i krisen fra torsdag d. 25. februar til og med mandag d. 1. marts, hvor kommunen afholder pressemøde. Der vil ydermere kun være fokus på den eksterne kommunikation, der primært foregår gennem pressen. Dette giver kun et lille indblik i sagsforløbet. Grunden til, at starten er interessant i denne sammenhæng, er fordi, det er i den første fase, at håndteringen går skævt for kommunen, hvilket man selv er klar over (7), og derfor kan teorien blive undersøgt i den første kritiske fase. Det skal retfærdigvis nævnes, at Brønderslev Kommune får bedre styr på krisekommunikationen senere i forløbet.

\section{Struktur}

Strukturen er præget af, at der ikke er noget formelt krisekommunikativt beredskab. Man har en kommunikationsstrategi, og det er blandt andet den, der får direktøren til at underrette chefkonsulenten, da han hører om, at politiet er ude og anholde forældrene, men man formår ikke som organisation at tænke i krisetermer. Et af de væsentligste punkter, hvor den manglende struktur bliver tydelig, er spørgsmålet om, hvem der skal tegne kommunen udadtil. Direktøren er klar til at være talsperson, men efter en drøftelse med borgmesteren bliver det hende, der påtager sig rollen i den første fase. Tre faktorer skal nævnes i den forbindelse. For det første skaber det usikkerhed hos nogle medarbejdere, fordi man ikke føler sig $100 \%$ tryg ved hendes udtalelser (6). For det andet skal informationen bevæge sig længere, hvilket gør den langsommere, specielt når der ikke nedsættes en formel krisestab før mandag. Og for det tredje fratager kommunen sig en mulighed for at „opgradere“ talspersonen. Havde direktøren håndteret kommunikationen kunne kommunaldirektøren have trådt ind, hvis sagen var blevet ved med at eskalere, som den gjorde. Herefter kunne borgmesteren være gået ind, hvis der var behov for det. Da sagen eskalerer, og der kommer faktuelle fejl frem i kommunikationen, har kommunen ikke mulighed for at optrappe på talspersonen. Man har sat topchefen ind, og det er dennes troværdighed, der rives fra hinanden. Selvom det ikke direkte kan påvises, så kan det heller ikke afvises, at den nyvalgte borgmester ser sagen som en mulighed for at markere sig. I kodeks for god offentlig topledelse er det første punkt, at man skal afklare sit ledelsesrum med den politiske ledelse (Forum for god offentlig topledelse 2005). På samme måde kan en formel kriseplan afklare det kommunikative rum, så det ikke bliver et tema i en krise. Det var ikke tilfældet i Brønderslev.

\section{Kultur}

Kulturen, forstået som krisebevidstheden, er også minimal.

Jamen, det er jo det, jeg har pisket mig selv med mange gange. Problemet er jo, at jeg skulle have fri dagen efter, og det var jeg egentlig sådan meget optaget af. Så jeg sagde bare sådan, nå, jamen det, så er der styr på det så, ja, ja. Okay jamen fint, og så tænkte jeg egentlig ikke mere over det (7). 
Citatet ovenfor omhandler 7's reaktion, da hun hører om sagen torsdag eftermiddag. Det illustrerer, at krisens mulige potentiale ikke fylder nok hos hende, selvom hun samtidig er den centrale aktør i arbejdet med mediesager $(2,3,4,6)$. Da krisen så efterfølgende springer ud, så formår kommunen heller ikke at agere som sin egen djævlens advokat.

Jeg tror, der sker det, at da vi sidder i den der krisegruppe der mandag morgen, der sidder der jo nogle fagfolk, som også meget på det tidspunkt jo siger, at vi har altså gjort det godt nok (...). Og der sker nok også det, at os, der ikke har det faglige kendskab til sagen, vi bliver simpelthen så glade, fordi de sidder der og fortæller, at de faktisk har gjort det godt nok. Så, yes, lad os da fortælle det. Hvor at der skulle have været en, der kunne stille de dumme spørgsmål, og det vil jeg sige, at det blev vi bedre til hen af vejen, men ikke der i starten (7).

Det paradoksale ved dette er, at der blandt socialrådgiverne selv kommer en diskussion af, om lovgivningen også var overholdt.

Hvis du spørger mine rådgivere, så vil nogle af dem sige, at lovgivningen ikke var overholdt (6).

Denne diskussion, der kunne være en hjælp i forhold til krisekommunikationen og krisehåndteringen, kommer aldrig frem til de personer, der står for håndteringen af krisen. Et andet element som Weick \& Sutcliffe (2007) identificerer hos $\mathrm{HRO}$ er, at man lytter til de personer, der arbejder med det i det daglige - de rigtige eksperter. Denne diskussion blandt kommunens eksperter kommer ikke frem til dem, der har med krisehåndteringen at gøre. Alt sammen indikerer, at den kulturelle krisebevidsthed halter hos Brønderslev Kommune.

\section{Demografi}

Hvad angår demografien, så er borgmesteren nyvalgt, men har dog tidligere erfaring med borgmesterembedet fra før kommunalreformen. Kommunaldirektøren er i sommerhus uden TV og radio, men med internet. Chefkonsulenten har fri om fredagen, og er derfor ikke på rådhuset. Den faglige leder er også ude af huset, men kommer på rådhuset i forbindelse med et møde. Da borgmesteren bliver talsperson, vælger direktøren at holde weekend som normalt, hvor han ikke har særligt fokus på sagens udvikling. Det gør blandt andet, at borgmesteren har svært ved at få fat i ham allerede fredag aften. Det lykkedes senere for vicekommunaldirektøren. Kommunen er med andre ord ekstremt sårbar i den første weekend. Selvom chefkonsulenten sparrer med borgmesteren over telefonen, så er der mange centrale medarbejdere, der er fraværende i den første weekend.

Der er ingen i kommunen, der har erfaring med kriser i denne målestok, og chefkonsulenten er den eneste, der har et decideret kursus i krisehåndtering. Dette betyder, at kommunen mangler viden i forhold til, hvordan den skal håndteres. Der mangler for det første viden om den interne organisering af krisen, ligesom der også mangler lidt forståelse for stakeholdernes (specielt pressens) måde at agere på i denne type af kriser. ${ }^{6}$

\section{Krisekommunikative budskaber}

Sagen bliver offentlig kendt fredag d. 26. februar, da det kommer frem, at kommunen har måttet fjerne otte børn fra en ejendom i Serritslev. ${ }^{7}$ De første beskrivelser i pressen vidner om en familie, der har levet i perioder uden vand, der er døde heste på ejendommen, og hjemmet er i forfald (TV2 Nord 26/2-2010:19.30). Brønderslev Kommune hører om udviklingen allerede torsdag eftermiddag, da de bliver kontaktet af politiet om, at de tager ud på ejendommen. Det betyder, at kommunen skal finde en akut plejefamilie til de otte mindreårige børn (5). Kommunikativt foretager kommunen sig ikke noget frem til sagen kommer i pressen. Brønderslev Kommunes borgmester, Lene Hansen (S), er igennem i TV2 News første gang fredag kl. 14.00 (7). Senere samme aften udtaler hun følgende.

\section{Efter min mening så har Brønderslev Kommune handlet hurtigt, professionelt, ansvarligt. Så snart vi har fået orientering fra skolen om, at der var nogle problemer, så har vi handlet. Og så kan man spørge, hvorfor har I ikke handlet før, hvorfor vidste I ikke noget før? De var lige kommet til kommunen. Skolen reagerer, vi reagerer. (...)Der følger jo ikke noget med [fra fraflytningskommu- nen, red.], som vi bliver alarmeret over. Man har ikke foretaget sig noget særligt omkring den her familie. Og de har jo børn på 18 og 20 år, og har derfor opholdt sig i kommunen i flere år, hvor man jo må have haft kendskab til deres problemer, men man har undladt at handle. Det er fuldstæn- dig uforståeligt (TV2 Nord 26/2-2010:19.30).}

To responsstrategier, jf. Tabel 1, er centrale i udtalelserne. For det første en nedtoningsstrategi, hvor kommunen gør opmærksom på, at der er handlet. Hermed forsøger borgmesteren at unddrage et eventuelt ansvar for det, der ser ud til at være foregået. Skylden lægges på de kommuner, hvor familien tidligere har boet, og således gør man op- 
mærksom på, at det er disse kommuner, der er ansvarlig for, at der ikke er grebet ind før. Faktisk gør borgmesteren opmærksom på, at kommunen har reageret, hvormed der er noget benægtelse over, at kommunen skulle have skyld i familiens tragiske situation. Dette kombineres med en benægtelsesstrategi, hvor scapegoaten bliver de kommuner, som tidligere har haft kommunen boende, hvormed ansvaret rettelig bør adresseres til disse. Begge disse strategier er der betænkeligheder ved i administrationen.

\section{(...)sådan nogle sager, de er altid så komplekse, at det er svært at stå ren i sådan en sag (...) jeg har sådan set ikke noget imod, at borgmesteren går ud og melder et eller andet ud omkring situatio- nen. Men det jeg var betænkelig ved, det var at navngive en kommune. Det var det, der lå i mine betænkeligheder (4).}

Således er de to strategier, der er kommunens forsvar i den pågældende sag, ikke noget, der er enighed om internt $\mathrm{i}$ kommunen. Der tegner sig således et billede af, at der er en konflikt mellem det politiske og administrative niveau i kommunen om de kommunikative strategier. Denne skillelinje kommunikeres også ud, da borgmesteren om fredagen ønsker en redegørelse fra hendes embedsmænd for at vurdere, om Brønderslev Kommune „kunne have reageret tidligere ved for eksempel at fjerne børnene tidligere“ (Nordjyske 27/2-2010:4-5). Dette budskab har én primær funktion, nemlig at købe tid, så man kan få styr på de faktuelle dele i sagen (7), men samtidig står meldingen også i kontrast til den relativt kategoriske afvisning tidligere om, at kommunen har gjort, hvad den skulle. Hvordan kan man handle professionelt og ansvarligt, hvis man skal finde ud af, om man kunne have reageret tidligere? Dette giver et indtryk af manglende konsistens og styring i krisekommunikationen, der kan forvirre stakeholderne i den retoriske arena.

I løbet af fredagen viser det sig ligeledes, at den kommune, som kommunen navngiver som familiens tidligere bopælskommune, er forkert. Guldborgsund Kommune, som man fejlagtigt anklager, viser sig at være Lollands Kommune, hvilket får Guldborgsunds borgmester til at gå i pressen, ligesom kommunaldirektøren henvender sig til sin kollega i Brønderslev Kommune, der via mail giver en undskyldning. Direktøren foreslår efterfølgende at lave en pressemeddelelse, hvor han tager ansvaret for fejlen, men det afvises af borgmesteren. Der udfærdiges også en pressemeddelelse, hvor Lene Hansen siger undskyld, samt lukker ned for pressen indtil hun har talt med sine embedsmænd, men denne sendes ikke ud (7). Da avismedierne kommer med historien lørdag morgen, som er første gang, at avismedierne omtaler sagen, handler historierne primært om den uvidenhed, der er omkring, hvor familien egentlig kommer fra (Politiken 27/2-2010, s. 3; Nordjyske 27/2-2010, s. 4-5), hvilket giver et indtryk af kaos i forhold til sagen. Det får borgmesteren til at udtale, at det ikke er Guldborgsund Kommune, men samtidig holder hun fast i, at problemet er opstået før, familien flyttede til Brønderslev Kommune - en gentagelse af de to responsstrategier.

Mandag d. 1. marts indkalder kommunen til pressemøde, hvor man præsenterer en redegørelse for pressen. Her præsenteres det, der kan præsenteres, under hensyntagen til tavshedspligten, og følgende budskaber trækkes frem.

(...)gøre det klart, at der ikke er tegn på, at de øvrige 8 børn har været udsat for misbrug, tvang eller lign. (...). Der er intet i undersøgelsen fra Skanderborg, der på nogen måde peger i retning af, at vi kan eller skal anvende tvangsbestemmelsen. (...)Skulle vi fjerne børnene tidligere i forløbet, så skal loven simpelthen laves om. (...) Det er korrekt, at familien ikke bor, som folk bor flest. (...) Kunne vi have gjort noget anderledes eller bedre? Det vil nogen mene. Jeg er selv meget tryg ved den omfattende redegørelse, jeg i dag har fået. Jeg ved at vores medarbejdere er dygtige og er anerkendt for det rundt omkring. (...)hvorfor i alverden vi dog ikke har fjernet de børn før? Det har vi altså ikke, fordi der ikke har været lovgrundlag for det. Debatten om dette skal adresseres til Christiansborg (Brønderslev 2010c).

I første omgang er der en benægtelse af de rygter, der har floreret om, at alle børnene har været udsat for misbrug. Efterfølgende sættes der fokus på Skanderborgs rolle i sagen, men uden at det er et angreb på denne aktør. I stedet er der tale om en retfærdiggørelse af de handlinger, som Brønderslev Kommune har foretaget - en nedtoningsstrategi, der allerede er anvendt tidligere. Det næste element, hvor kommunen taler Christiansborg ind i sagen, og henviser til lovgivningen, er et forsøg på unddragelse af ansvar ved at gøre lovgivningen til scapegoat. Dette er interessant, fordi det betyder, at kommunen italesætter sig selv som en agent for Christiansborg, hvormed ansvaret bør placeres hos principalen - noget der naturligvis afvises af den nytiltrådte minister. Brunsson \& Sahlin-Andersson (2000) har beskrevet, hvordan en offentlig organisation kan anskues på tre forskellige måder, hvoraf den ene er en agent. Agenten har et begrænset handlingsrum, grænserne til omverdenen er uklare og ressourcerne tildeles fra den hierarkiske overordnede aktør (principal). Anskuelsen strider mod den traditionelle måde at anskue en kom- 
mune på, hvor den er en selvstændig organisation, der selv har ansvaret for sit virke. Ved at bruge lovgivningen som scapegoat, så italesættes der et organisatorisk hierarki ind i sagen, hvor kommunen prøver at tydeliggøre, at de skal følge en lovgivning, der vedtages på Christiansborg, og at ansvaret derfor kan flyttes herind - noget som der altså er uenighed om blandt socialrådgiverne.

Ydermere roses medarbejderstaben, hvilket kan tolkes som en påmindelsesstrategi, hvor der påmindes om medarbejdernes gode ry i faglige kredse - et element der også fungerer som kommunikation indadtil til de hårdt pressede socialrådgivere (4). Hermed fungerer denne strategi i lige så høj grad som autokommunikation (Hansen 2011) til kommunen selv, hvor der gives en opbakning til de medarbejdere, der er under hårdt eksternt pres.

\section{Diskussion}

De kommunikative strategier, som kommunen anvender i denne første indledende fase, giver et tydeligt indtryk af, at ansvaret ikke skal placeres hos Brønderslev Kommune. Både lovgivning og andre kommuner bruges som scapegoat, hvilket også er med til at nedtone kommunens eget ansvar. Brugen af lovgivningen som scapegoat er interessant på flere måder. Efter flere års NPM-inspirerede reformer (Hansen et. al. 2008) er der sket en opsplitning af den offentlige sektor, men samtidig foregår meget lovgivning på Christiansborg. Udviklingen kan karakteriseres som en decentraliseret centralisering, hvor opgaver og ansvar er udlagt til kommuner og institutioner, men samtidig er udformningen og målene styret af det centrale niveau. Det ikke specielt vellykkede forsøg på at italesætte ansvaret på Christiansborg viser, at i det kommunikative spil, der foregår mellem centraladministration og kommuner, er kommunerne dårligere stillet $\mathrm{i}$ brugen af scapegoat som et slagkraftigt argument, mens det er blevet nemmere for centraladministrationen. Det helt store problem med brugen af scapegoat er dog, at de andre giver igen, og når kommunen vælger at pege fingre af alle andre, så bliver presset tilbage endnu stærkere.

Der anvendes også en påmindelsesstrategi, der kan anses som værende autokommunikation til medarbejderne. Men strategien kan også anskues som et forsvar af ledelsen i kommunen. En frikendelse af medarbejderne er samtidig en frikendelse af ledelsen, der sidder med det overordnede ansvar, så derfor kan påmindelsen også ses som en benægtelse af ansvaret. Den tidlige brug af scapegoat giver et indtryk af, at kommunen er meget hurtig til at frikende sig selv, selvom det faktisk aldrig sker eksplicit. Disse strategier kombineret gør paradoksalt nok, at kommunen kommer til at lukke sig om sig selv, selvom der fra starten lægges op til at håndtere det meget åbent (7). I denne åben- og tilgængelighed over for medierne kom- munikerer kommunen et forsvar for sig selv, der aldrig slår igennem i de historier, der kommer frem i medierne i den første fase, og således er der blandt nogle borgere en opfattelse af, at kommunen ikke gjorde nok for børnene i familien, hvilket eksempelvis kan ses i diverse debatfora på nettet.

Interessant er det, at kommunen på intet tidspunkt benytter en genopbygningsstrategi. Det er ellers her, at organisationen kunne påtage sig et ansvar for det, der er sket. Dette sker først meget sent i forløbet, og på tidspunkter, hvor andre instanser fremlægger deres syn på sagen. I første omgang, da Ankestyrelsen udtaler kraftig kritik af kommunen og $\mathrm{i}$ anden omgang, da byretten dømmer forældrene i skyldsspørgsmålet. Meget kunne muligvis være undgået, hvis man havde erkendt sit ansvar tidligere i forløbet.

Hvad angår krisehåndteringen, så er Brønderslev Kommune selv klar over, at den første weekend ikke blev håndteret godt nok.

Det er simpelthen, torsdag, fredag, lørdag det er der, hvor den sag, den bare ryger for os. Jeg tror, vi kunne have håndteret alt det andet anderledes, hvis bare vi havde gjort de der ting. Det er jo der, hvor teorien den bare rammer plet i forhold til at sige, at det helt essentielle det er, hvordan en krise, den bliver håndteret fra start. Og det er det virkelig (7).

Spørgsmålet er så, hvad der gik galt? For det første var strukturen ikke på plads. Det betød, at man ikke fik indsamlet fakta i tide, og derfor fik kommunikeret noget faktuelt forkert med det resultat, at troværdigheden dykkede. Det betød også, at der ikke var en plan for, hvem der udtalte sig, og det kan diskuteres, hvor rigtigt det var, at det var borgmesteren, der endte med at udtale sig. Strukturen kunne have givet nogle retningslinjer for, hvem der udtaler sig i hvilke typer af sager, så det ikke bliver et issue under krisen. For det andet var krisebevidstheden ikke stærk nok hos kommunen, hvor man ikke var klar nok på krisens potentielle skade på kommunens omdømme. Man formåede heller ikke at stille de dumme spørgsmål, og derfor blev hele organisationen rullet ind i fagpersonernes udsagn om, at kommunen havde håndteret det godt nok, selvom nogle socialrådgivere var uenige i den betragtning. For det tredje viser sagen, at organisationen blev ramt af krisen på et tidspunkt, hvor den var ekstrem sårbar grundet fravær af nøglepersoner og generel manglende kriseerfaring.

Senere får kommunen bedre styr på krisehåndteringen. For det første får man nedsat en krisestab, hvilket skaber mere ro internt i kommunen. For det andet får 
man skiftet talspersonen (til direktøren), så det ikke er et tema internt $\mathrm{i}$ organisationen. For det tredje bliver kommunen mere bevidst om, hvor væsentlig krisekommunikationen er. Dette indikerer, at der med ændringen af strukturen og kulturen også er bedre styr på krisekommunikationen. Således er der en tentativ bekræftelse på første del af hypotesen om, at en god krisekommunikation starter med den interne organisering af krisen. Det har de nu lært i Brønderslev Kommune.

\section{Altså vi har betalt nogle rigtig dyre lærepenge, men hold kæft hvor har vi lært meget (7).}

Til gengæld kan manglerne i krisekommunikationen ikke tilskrives det generelle strategiske kommunikationsfokus i Brønderslev Kommune, der følger flere af KL's anbefaling. Kommunikation er forankret i topledelsen, og det er forsøgt at opdrive de gode historier rundt om i kommunen. Kulturen bærer også præg af, at der er fokus på det kommunikative aspekt af kommunens virke, men på demografien er man sårbar, hvilket man godt er klar over (2). Således er der indikationer på, at en stærk krisekommunikation starter med kriseorganiseringen og ikke den generelle kommunikationsindsats.

\section{Litteraturliste}

Andersen, N.B. 2008. 'Risici og ramthed - vedtagelser, performance og definitionsmagt. Ph.d. afhandling ved Roskilde Universitetscenter.

Andersen, L.B. 2010. 'Forskningskriterier' i Andersen, L.B. Hansen, K.M. \& Klemmensen, R (eds.). 'Metoder i statskundskab', pp. 97113. København. Hans Reitzels Forlag.

Antoft, R. \& Salomonsen, H.H. 2007. 'Det kvalitative casestudium introduktion til en forskningsstrategi' i Antoft, R., Jacobsen, M.H., Jørgensen, A. \& Kristiansen, S. (eds.), Håndværk \& Horisonter Tradition og nytænkning i kvalitativ metode, pp. 29-57. Odense. Syddansk Universitetsforlag

Benoit, W.L. 1995. Accounts, Excuses and Apologies - A Theory of Image Restoration Strategies. Albany. State University of New York Press.

Boin, A. \& t' Hart, P. 2003. 'Public Leadership in Times of Crisis: Mission Impossible?' i Public Administration Review, vol. 63, no. 5, pp. 544-553.

Boin, A. t' Hart, P. Stern, E. \& Sundelius, B. 2005. The Politics of Crisis Management - Public Leadership Under Pressure. New York. Cambridge University Press.

Brunsson, N. \& Sahlin-Andersson, K. 2000. 'Constructing Organizations: The Example of Public Sector Reform' i Organization Studies, vol. 21, no. 4, pp. 721-746.

Bryman, A. 2008 [2001]. 'Social Research Methods, third edition'. Oxford. Oxford University Press.

Brønderslev 2010a. 'Pressemeddelelse: Brønderslev Kommune får kritik fra ankestyrelsen'.

Brønderslev 2010b. 'Redegørelse fra Brønderslev Kommune vedr. Serritslev-sag'.
Brønderslev 2010c. 'Klar til at komme på forsiden - krisekommunikationsstrategi for Brønderslev Kommune'.

Christensen, T. \& Lægreid, P. 2006 (eds). 'Autonomy and Regulation: coping with agencies in the modern state'. Northampton, Massachusetts. Edward Elgar Publishing, Inc.

Christensen, T. \& Lægreid, P. 2009. 'Democracy and administrative policy: Contrasting elements of NPM and post-NPM'. Working Paper 11. Stein Rokkan Centre for Social Studies. Unifob AS.

Christensen, T. Lægreid, P. Roness, P.G. Røvik, K.A. 2004. Organisasjonsteori for offentlig sector - Instrument, kultur, myte. Oslo: Universitetsforlaget.

Coombs, W.T. 2007a [1999]. Ongoing Crisis Communication - Planning, Managing and Responding. Second edition. Thousand Oakes. SAGE Publications.

Coombs, W.T. 2007b. 'Protecting Organization Reputations During a Crisis: The Development and Application of Situational Crisis Communication Theory' i Corporate Reputation Review, vol. 10, no. 3, pp. 163-176.

Danske Kommuner 2010. Nyhedsmagasinet 4. november, no. 31.

Egeberg, M. 1992. 'Konstruktiv statsvitenskap og forvaltningspolitikk' i Norsk statsvitenskapelig tidsskrift, Nr. 3, 8. årgang, pp. 185-204.

Egeberg, M. 2003. 'How Bureaucratic Structure Matters: An Organizational Perspective' i Peters, B.G. \& Pierre, J (eds.) 'Handbook of Public Administration', pp.109-126. Thousand Oakes. SAGE Publications Ltd.

Flyvbjerg, B. 2006. 'Five Misunderstandings About Case-Study Research' i Qualitative Inquiry, vol. 12, no. 2, pp. 219-245. SAGE Publications.

Forum for god offentlig topledelse. 2005. 'Public Governance - Kodeks for god offentlig topledelse i Danmark'. København. Mkom Danmark Aps.

Frandsen, F. Olsen, L.B. Amstrup, J.O. \& Sørensen, C. 2005. 'Den kommunikerende kommune'. København. Børsens Forlag.

Gerring, J. 2005. 'Causation: A Unified Framework for the Social Sciences' i Journal of Theoretical Politics, vol. 17(2), pp. 163-198.

Hansen, K. Bjørnholt, B. Jespersen, P.K. Nielsen, J.A. \& Salomonsen, H.H.. 2008. Nye kommuner i støbeskeen - om organisering og styring i de nye kommuner. København. Handelshøjskolens Forlag.

Hansen, H. 2011. 'Kommunikation skaber din organisation'. København. Hans Reitzels Forlag

Johansen, W. \& Frandsen, F. 2007. Krisekommunikation - Når virksomheders image og omdømme er truet. Frederiksberg: Forlaget Samfundslitteratur.

Johansen, W. \& Frandsen, F. 2009. 'Institutionalizing Crisis Communication in the public Sector: An Explorative Study in Danish Municipalities' in International Journal of Strategic Communication, vol. 3, issue 2 pp. 102-115

Kjær, U. Hjelmar, U. \& Olsen, A.L. 2010. ' Municipal Amalgamations and the Democratic Functioning of Local Councils: The Case of The Danish 2007 Structural Reform' in Local Government Studies, vol. 36, No. 4, pp. 569-585.

KL 2008. 'Temaguide: Presse- og krisehåndtering'. http://www.kl.dk/ ImageVault/Images/id_29335/ImageVaultHandler.aspx

KL 2009. 'Kommunalbestyrelsen og medierne - sådan bliver vi bedre til at sætte dagsordenen i medierne!' http://www.kl.dk/ImageVault/ Images/id_38411/ImageVaultHandler.aspx

Lund, A.B. \& Nyegaard, M. 2008 'Kommunaldirektøren og kommunikationsstrategien'. København. KL.

Meyer, J.W. Boli, J. \& Thomas, G.M. 1987. 'Ontology and rationalization in the western account' i Thomas, G.M. Meyer, J.W. Ramirez, F.O. \& Boli, J. 'Constituting state, society and the individual', pp. 12-37. Newbury Park, CA. Sage. 
Miles, M.B. \& Huberman, A.M. 1994. 'Qualitative Data Analysis, Second Edition'. Thousand Oakes. SAGE Publications Inc.

Pearson, C.M. \& Mitroff, I.I. 1993. 'From crisis prone to crisis prepared. A framework for crisis management', in The Executive, vol. 7, no. 1, pp. 48-59.

Peters, B.G. 1998. 'Administration in the year 2000: serving the client' in International Journal of Public Administration, vol. 21, issue 12, pp. 1759-1776.

Scott, W.R. 2003. Organizations: Rational, Natural and Open Systems, fifth edition. New Jersey. Pearson Education, Inc.

Weick, K.E. \& Sutcliffe, K.M. 2007 [2001]. 'Managing the Unexpected: Resilient performance in an Age of Uncertainty', second edition. San Francisco. John Wiley \& Sons, Inc.

Yin, R.K. 2009 [1984]. 'Case Study Research - Design and Methods, Fourth Edition'. Thousand Oakes. SAGE Publications, Inc.

\section{Noter}

1 Sagens forløb strækker sig dog over 15 måneder fra anholdelse til dom, der faldt i starten af sommeren 2011. Undervejs er sagen kommet op med forskellige vinkler.

2 Udviklingen kan dog primært forklares ved at det er sket i kommuner, der er blevet lagt sammen som en følge af kommunalreformen.

3 Det skal her nævnes, at Egeberg faktisk opererer med fire variable, hvoraf den sidste (locus), der dækker over fysisk placering af beslutningstagerne, ikke er inddraget i denne undersøgelse.

4 Undersøgelsen er del af en afhandling, der bygger på et komparativt case design.

5 Denne går dog under titlen chefkonsulent, og fokus i stillingen er lagt på strategisk kommunikation og ikke så meget det daglige rugbrødsarbejde i forbindelse med kommunikationen.

6 Brønderslev kommune føler sig forfulgt af pressen, hvilket kommer til udtryk i flere angreb på journalister og medier. Alt sammen noget, der skaber mere omtale af sagen, og lægger større pres på kommunen.

7 Det viser sig senere, at familien består af ti børn. Den ældste datter er farens biologiske datter. Moren har to børn fra et tidligere forhold, og så har de sammen fået syv børn på 11 år.

\section{Appendix A.}

\section{Tidstabel over Brønderslevsagen}

25. februar 2010. Politiet anholder forældrene, og de mindreårige børn anbringes hos en midlertidig plejefamilie.

26. februar 2010. Forældrene fremstilles i grundlovsforhør og varetægtsfængsles. Sagen bliver offentlig kendt.
28. februar 2010. Socialminister Benedikte Kiær (K) melder offentlig ud, at hun ønsker en redegørelse fra kommunen.

1. marts 2010: Brønderslev Kommune indkalder til pressemøde kl. 17.00, hvor de præsenterer en foreløbig redegørelse.

3. marts 2010. Socialministeren er ikke beroliget efter at have læst redegørelsen. Derfor skal Ankestyrelsen kulegrave sagens 15 -årige lange forløb.

8. marts TV 2 nyhederne kommer i besiddelse af den indsendte redegørelse, der indeholder fortrolige oplysninger. Brønderslev Kommune melder denne læk til politiet. Det kommer ligeledes frem, at nogle medarbejdere fra kommunen er inviteret til møde i socialministeriet ugen efter. Socialministeren inviteres til Brønderslev af borgmesteren for at få et indblik i kommunens virke.

14. maj 2010. Politiet offentliggør, at de sigter forældrene for misrøgt.

25. maj 2010. Da kommunen erfarer, at en journalist fra Politiken har fået adgang til de ældste børn i plejefamilien, vælger man at fjerne børnene før tid fra den midlertidige plejefamilie.

30. juni 2010. Ankestyrelsen kommer med sin rapport, hvor der er kraftig kritik af Brønderslev Kommune.

7. august 2010. Faren stikker af fra retspsykiatrisk afdeling i Aalborg.

24. september 2010. Det sociale nævn afgør, at regningen for anbringelserne for de mange børn, skal sendes til Lollands Kommune.

19. februar 2011. Referat af anklageskriftet offentliggøres.

28. april 2011. Retssagen mod forældrene starter.

24. maj 2011. Ankestyrelsen fastholder efter anke fra Lollands Kommune, at det sociale nævn havde ret, da de afgjorde, at Lollands Kommune skal betale regningen for anbringelserne.

6. juni 2011. Retten kender begge forældre skyldige i næsten samtlige anklagepunkter. Om aftenen viser DR dokumentaren „Børnene fra Brønderslev“.

21. juni 2011. Strafudmålingen finder sted. Begge forældre anker skyldsspørgsmålet på stedet med krav om frifindelse. 